\title{
A STUDY OF ECHOCARDIOGRAPHIC FINDINGS IN HIV PATIENTS WITH CARDIAC SYMPTOMS AT STANLEY MEDICAL COLLEGE
}

Sundaramoorthy Ganesan ${ }^{1}$, Ashokkumar Subramaniam², Natarajan Kandasamy33, Danraj Subramani, Vijayanand Radhakrishnan ${ }^{5}$

1 Professor, Department of General Medicine, Government Stanley Medical College.

${ }^{2}$ Associate Professor, Department of General Medicine, Government Stanley Medical College.

${ }_{3}^{3}$ Assistant Professor, Department of General Medicine, Government Stanley Medical College.

${ }_{4}^{4}$ Assistant Professor, Department of General Medicine, Government Stanley Medical College.

5 Assistant Professor, Department of General Medicine, Government Stanley Medical College.

ABSTRACT
BACKGROUND
The cardiovascular complications of HIV can be directly due to the virus itself due to the associated risk factors like smoking and
hyperlipidaemias associated in HIV patients or due to the adverse effect the antiretroviral therapy. Earlier heart diseases in HIV
patients were mostly found in autopsy series. But with development of new diagnostic methods, it is now possible to diagnose the
cardiovascular complications of HIV in patients at an earlier time.

\section{MATERIALS AND METHODS}

Patients from ART Clinic, Medical Ward in Stanley Hospital from February to July 2013 who are positive for HIV antibodies were included in the study. After getting informed consent from the patient, history and clinical examination was obtained from the patient followed by investigations. Apart from all routine investigations like complete blood count, renal function test, lipid profile, liver function test, ultrasonogram of abdomen, chest X-ray, electrocardiogram, echocardiography was done for all these patients and analysis was done from the information from all the above.

\section{KEYWORDS}

Echocardiography, HIV, AIDS.

HOW TO CITE THIS ARTICLE: Ganesan S, Subramaniam A, Kandasamy N, et al. A study of echocardiographic findings in HIV patients with cardiac symptoms at Stanley Medical College. J. Evolution Med. Dent. Sci. 2016;5(78):5848-5852, DOI: $10.14260 /$ jemds/2016/1318

\section{INTRODUCTION}

Acquired immunodeficiency syndrome is caused by human immunodeficiency virus, which belongs to class of retroviridae. AIDS has become the most dangerous pandemic, which has plagued us in the last two decades. AIDS affects almost all systems in our body.

Due to increased discovery of new anti-retroviral drugs against HIV, the survival of the patients has considerably increased and hence the cardiovascular complications of AIDS is more prevalent now. ${ }^{1}$

The cardiovascular complications of HIV can be directly due to the virus itself due to the associated risk factors like smoking and hyperlipidaemias associated in HIV patients or due to the adverse effect of the antiretroviral therapy.

Earlier heart diseases in HIV patients were mostly found in autopsy series. But with development of new diagnostic methods, it is now possible to diagnose the cardiovascular complications of HIV in patients at an earlier time.

Of the diagnostic modalities for early detection of cardiovascular complications, a simple but still a very effective tool is cardiac echocardiography.

Financial or Other, Competing Interest: None.

Submission 26-07-2016, Peer Review 19-08-2016,

Acceptance 25-08-2016, Published 29-09-2016.

Corresponding Author:

Dr. Ashokkumar Subramaniam

No. 41 GST Road,

Meenambakkam, Chennai-600027.

E-mail: Drashokstanley2459@gmail.com

DOI: $10.14260 / \mathrm{jemds} / 2016 / 1318$
The spectrum of cardiovascular conditions, which can be diagnosed using imaging modalities include the following which are discussed in detail in later stages. ${ }^{2,3}$

1. Pericarditis.

2. Pericardial effusion.

3. Endocarditis.

4. Myocarditis.

5. AIDS related malignancy like Kaposi sarcoma and lymphomas.

6. Pulmonary hypertension.

7. Cardiomyopathy.

8. Coronary vascular diseases.

9. Thrombosis, embolism, vasculitis and aneurysms.

Thus, it is now important to screen regularly for cardiac complications in HIV patients to initiate early treatment and thus further improving the survival rate and increase the quality of life of HIV patients. 4

\section{OBJECTIVE}

1. To study pattern of cardiac involvement in HIV patients.

2. To know incidence of various cardiac diseases in our population.

3. To compare results with available literature.

\section{MATERIALS AND METHODS}

- Place of Study: Department of Medicine, Art Clinic, Stanley Medical College Hospital.

- Duration: February 2013 to July 2013.

- Study Design: Cross-Sectional Study

- Patient Selection: HIV positive patients, HIV patients on HAART. 


\section{Exclusion Criteria}

1. Known coronary artery disease patients and other known heart disease patients with HIV.

2. Known hypertensive and diabetic patients.

3. Known COPD patients

4. Renal failure.

Sample Size: 116 patients are studied.

\section{METHODOLOGY}

Patients from ART Clinic, Medical Ward in Stanley Hospital from February to July 2013, who are positive for HIV antibodies were included in the study.

After getting informed consent from the patient, history and clinical examination was obtained from the patient followed by investigations.

Apart from all routine investigations like complete blood count, renal function test, lipid profile, liver function test, ultrasonogram of abdomen, chest X-ray and electrocardiogram.

Echocardiography was done for all these patients and analysis was done from the information from all the above.

\section{RESULTS}

\section{Gender Distribution}

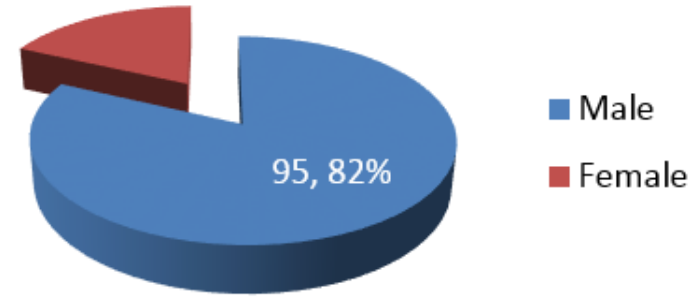

\begin{tabular}{|c|c|c|c|}
\hline Gender & Male & Female & Total \\
\hline Number & 95 & 21 & 116 \\
\hline Percentage & 82 & 18 & 100 \\
\hline
\end{tabular}

$82 \%$ of the patients were males and $18 \%$ were females.

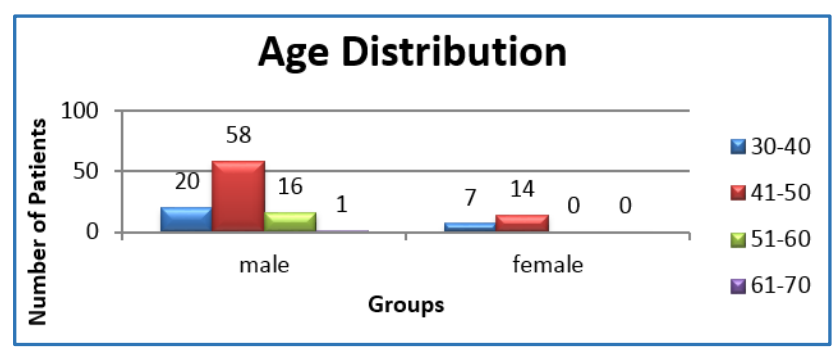

\begin{tabular}{|c|c|c|c|c|}
\hline Age Group & Male & $\mathbf{\%}$ & Female & $\mathbf{\%}$ \\
\hline $30-40$ & 20 & 21.05 & 7 & 33.33 \\
\hline $41-50$ & 58 & 61.05 & 14 & 66.67 \\
\hline $51-60$ & 16 & 16.84 & 0 & 0.00 \\
\hline $61-70$ & 1 & 1.05 & 0 & 0.00 \\
\hline Total & $\mathbf{9 5}$ & $\mathbf{1 0 0}$ & $\mathbf{2 1}$ & $\mathbf{1 0 0}$ \\
\hline
\end{tabular}

\begin{tabular}{|c|c|c|}
\hline Age & Male & Female \\
\hline $\mathrm{N}$ & 95 & 21 \\
\hline Mean & 45.20 & 41.52 \\
\hline $\mathrm{SD}$ & 5.84 & 6.09 \\
\hline P value & \multicolumn{2}{|c|}{0.107} \\
Unpaired ' $\mathrm{t}$ ' test & \multicolumn{2}{|c|}{} \\
\hline
\end{tabular}

In our study, majority of the patients are in the age group 41-50 years and only $17 \%$ of the males and no females above 50 years of age. By conventional criteria, age difference between males and females is considered to be not statistically significant since $\mathrm{p}>0.05$. This establishes the fact that in spite of difference in the number of observations in each gender group, we are dealing with statistically similar groups.

\section{Cardiac Symptoms}

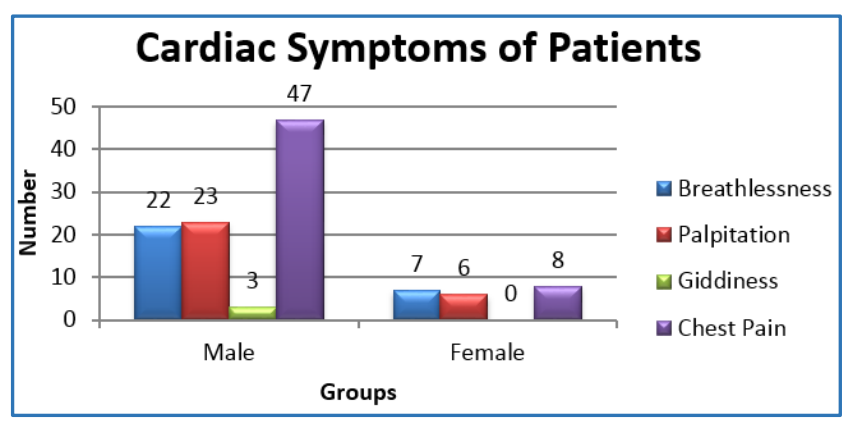

\begin{tabular}{|c|c|c|c|c|}
\hline $\begin{array}{c}\text { Cardiac } \\
\text { Symptoms of } \\
\text { Patients }\end{array}$ & Male & $\mathbf{\%}$ & Female & $\mathbf{\%}$ \\
\hline Breathlessness & 22 & 23 & 7 & 33 \\
\hline Palpitation & 23 & 24 & 6 & 29 \\
\hline Giddiness & 3 & 3 & 0 & 0 \\
\hline Chest Pain & 47 & 49 & 8 & 38 \\
\hline Total & $\mathbf{9 5}$ & $\mathbf{1 0 0}$ & $\mathbf{2 1}$ & $\mathbf{1 0 0}$ \\
\hline
\end{tabular}

The most common presenting cardiac symptom was chest pain $(43.5 \%)$, while the least common was giddiness $(1.5 \%)$. Breathlessness and palpitation were present in $28 \%$ and $26.5 \%$ of the patients, respectively. Multiple complaints were common and $38 \%$ of the patients had more than one symptom.

Echocardiographic Diagnosis

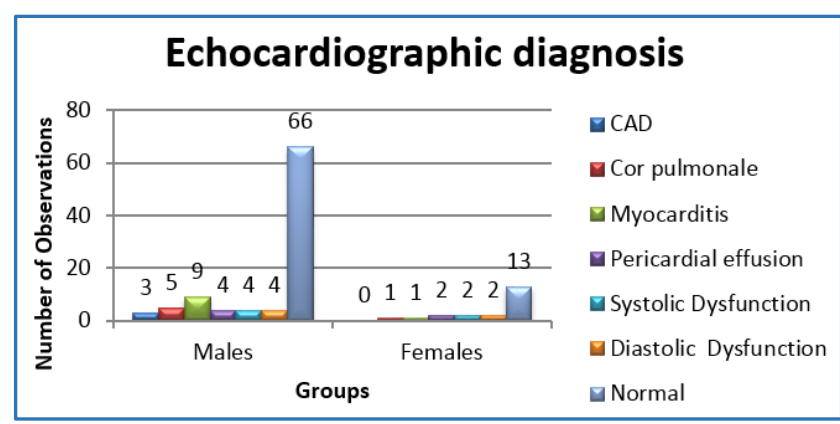

\begin{tabular}{|c|c|c|c|c|}
\hline $\begin{array}{c}\text { ECHO } \\
\text { Diagnosis }\end{array}$ & Males & $\mathbf{\%}$ & $\begin{array}{c}\text { Femal } \\
\text { es }\end{array}$ & $\mathbf{\%}$ \\
\hline CAD & 3 & 3 & 0 & 0 \\
\hline Cor pulmonale & 5 & 5 & 1 & 5 \\
\hline Myocarditis & 9 & 9 & 1 & 5 \\
\hline $\begin{array}{c}\text { Pericardial } \\
\text { effusion }\end{array}$ & 4 & 4 & 2 & 10 \\
\hline $\begin{array}{c}\text { Systolic } \\
\text { Dysfunction }\end{array}$ & 4 & 4 & 2 & 10 \\
\hline $\begin{array}{c}\text { Diastolic } \\
\text { Dysfunction }\end{array}$ & 4 & 4 & 2 & 10 \\
\hline Normal & 66 & 69 & 13 & 62 \\
\hline Total & $\mathbf{9 5}$ & $\mathbf{1 0 0}$ & $\mathbf{2 1}$ & $\mathbf{1 0 0}$ \\
\hline
\end{tabular}

The most common echocardiographic diagnosis was myocarditis, pericardial effusion, systolic dysfunction and 
diastolic dysfunction, each at $7 \%$ respectively; 65.55 of the

study subjects were significantly normal.

Demographic and Clinical Characteristics of Echocardiographic Diagnoses

\begin{tabular}{|c|c|c|c|c|c|c|c|}
\hline & CAD & $\begin{array}{c}\text { Cor } \\
\text { pulmonale }\end{array}$ & Myocarditis & $\begin{array}{c}\text { Pericardial } \\
\text { Effusion }\end{array}$ & $\begin{array}{c}\text { Systolic } \\
\text { Dysfunction }\end{array}$ & $\begin{array}{c}\text { Diastolic } \\
\text { Dysfunction }\end{array}$ & Normal \\
\hline $\mathrm{N}$ & 3 & 6 & 10 & 6 & 6 & 6 & 79 \\
\hline $\begin{array}{l}\text { Mean (SD) Age } \\
\text { (Years) }\end{array}$ & $46.7(4.2)$ & $45.8(5.2)$ & $40.8(4.3)^{*}$ & $39.3(6.9)^{*}$ & $41.3(8.9)$ & 43.8 (3.8) & $45.5(5.90$ \\
\hline Males (\%) & 100 & 83 & 90 & 67 & 67 & 67 & 84 \\
\hline $\begin{array}{l}\text { Mean (SD) SBP } \\
(\mathrm{mmHg})\end{array}$ & $\begin{array}{l}110.7 \\
(19.7)\end{array}$ & $115(5.2)^{*}$ & $109.4(5.7)^{*}$ & $104.7(8.2)$ & $114(8.4)$ & $115(3.7)$ & $\begin{array}{l}120.1 \\
(9.7)^{*}\end{array}$ \\
\hline $\begin{array}{l}\text { Mean (SD) DBP } \\
(\mathrm{mmHg})\end{array}$ & $79.3(16.8)$ & 77 (5.3) & $71.2(4.8)^{*}$ & $73.3(7.2)$ & $69.7(5.1)^{*}$ & $71.3(5.0)$ & $75.6(7.7)^{*}$ \\
\hline $\begin{array}{l}\text { Mean (SD) Pulse } \\
\text { Rate (b/min) }\end{array}$ & $84.7(10.5)$ & $115.7(4.6)^{*}$ & $116.3\left(5.80^{*}\right.$ & $100(1.8)$ & $88(9.2)$ & $81.8(7.0)$ & $81.5(7.4)^{*}$ \\
\hline $\begin{array}{l}\text { Mean (SD) Hb } \\
(\mathrm{g} / \mathrm{dL})\end{array}$ & $8.7(0.5)$ & $8.4(1.4)$ & $8.5(1.0)$ & $9.7(0.8)$ & $9.2(0.6)^{*}$ & $8.8(1.0)^{*}$ & $8.0(1.1)$ \\
\hline $\begin{array}{c}\text { Mean (SD) WBC } \\
\text { Count in } \\
\text { cells } \times 109 / \mathrm{L} \\
\end{array}$ & $5.7(0.03)^{*}$ & $11.8(2.7)^{*}$ & $12.1(0.09)^{*}$ & $11.1(0.6)^{*}$ & $5.7(0.8)^{*}$ & $5.2(0.8)$ & $4.6(1.5)$ \\
\hline $\begin{array}{c}\text { Mean (SD) Serum } \\
\text { Creatinine } \\
(\mu \mathrm{mol} / \mathrm{L})\end{array}$ & $83(15)$ & $93(16)$ & 93 (19) & $82(18)$ & $72(17)^{*}$ & $100(9)$ & $102(23)$ \\
\hline $\begin{array}{c}\text { Mean (SD) Serum } \\
\text { Cholesterol } \\
(\mathrm{mmol} / \mathrm{L})\end{array}$ & $\begin{array}{c}1.74 \\
(0.09)^{*}\end{array}$ & $1.91(0.07)$ & $1.87(0.05)$ & $1.86(0.04)$ & $2.10(0.45)$ & $1.78(0.17)$ & $\begin{array}{c}1.90 \\
(0.16)\end{array}$ \\
\hline $\begin{array}{l}\text { Mean (SD) CD4 } \\
\text { Cell Count } \\
\text { (cells } / \mu \mathrm{L} \text { ) }\end{array}$ & $503(18)^{*}$ & $300(66)^{*}$ & $88(23)^{*}$ & $352(136)^{*}$ & $510(105)^{*}$ & $562(78)^{*}$ & $\begin{array}{c}238 \\
(192)^{*}\end{array}$ \\
\hline$\%$ on ART & 100 & 100 & 100 & 100 & 83 & 100 & 92 \\
\hline $\begin{array}{c}\text { Mean (SD) } \\
\text { Duration on ART } \\
\text { (Years) }\end{array}$ & $2.3(0.06)$ & $2.3(1.2)$ & $2(0.08)$ & $2.6(0.5)$ & $2.3(1.2)$ & $2.5(0.5)$ & $2.3(0.9)$ \\
\hline \multicolumn{8}{|c|}{ Presenting Cardiac Symptoms (n)** } \\
\hline Palpitations & $0 *$ & $2 *$ & 6 & $2 *$ & $2 *$ & $1 *$ & 30 \\
\hline SOB & 3* & $6^{*}$ & $6^{*}$ & 5* & $3^{*}$ & $3^{*}$ & 35 \\
\hline Chest Pain & 3* & $2 *$ & 7* & 3* & 5* & 2* & 34 \\
\hline Giddiness & 0 & 0 & 0 & 0 & 0 & 0 & 3 \\
\hline
\end{tabular}

- $\mathrm{P}<0.05,{ }^{* *}$ Multiple diagnosis present

- As shown in Table 2, the echocardiographic diagnoses did not differ significantly between men and women or between patients on ART and those not on ART.

\section{DISCUSSION}

HIV infection is a pandemic now. Its incidence and prevalence is increasing rapidly. The disease affects all the systems in the body. But cardiac involvement in HIV infection is common, but not clinically appreciated. Cardiac involvement in HIV infection is common and occurs quite early in disease process. Our study showed that majority of patients with HIV infection had echocardiographic findings, which were clinically significant. This shows that echocardiography was an essential tool for diagnosis of subclinical cardiac abnormalities and it will help in instituting management at an earlier stage. The subjects in our study resembled a typical HIV cohort. In our study, $82 \%$ of the patients were males and $18 \%$ were females. Majority of the patients are in the age group 41-50 years and only $17 \%$ of males and no females above 50 years of age. The male-female ratio is 4.5:1. All these findings were consistent with the key findings of HIV estimations 2012 report by NACO. All the patients presented with symptoms of cardiac disease; $32 \%$ of the patients were confirmed with cardiac disease based on invasive cardiac investigations; 58 (45.5\%) of the patients had
CD4 count less than $200,531 \%$ had CD4 count between 201 350 and $23.5 \%$ had CD4 count more than 350; 109 patients (91\%) were on Anti-Retroviral Therapy and 9\% are not on ART.

\section{The most common Echocardiographic Diagnosis was}

1. Myocarditis.

2. Pericardial effusion.

3. Systolic dysfunction.

4. Diastolic dysfunction, each at $7 \%$ respectively; $65.55 \%$ of the study subjects were significantly normal.

\section{HIV and Coronary Artery Disease}

In our study HIV patients with CAD presented with Lower cholesterol levels, higher White Blood Cell (WBC) count, higher CD4 cell count and symptoms of palpitations, breathlessness and chest pain. 5

Traditional risk factors lead to increased coronary artery disease in the population. HIV infection is independently associated with increased cardiovascular risk.

ART also contributes to risk of coronary artery disease, especially in patients on protease inhibitors. Usually increased cholesterol levels, smoking and decreased CD4 levels are recognised risk factors for CAD. But in our study apart from smoking status other variables are not in tune with previous 
studies, which have found increased incidence of heart attacks and other cardiovascular events among HIV infected individuals.

\section{HIV and Cor Pulmonale}

Incidence of pulmonary hypertension was significant in our study. In our study, HIV patients with cor pulmonale presented with lower systolic BP, higher mean resting pulse rate, higher White Blood Cell (WBC) count, higher CD4 cell counts and symptoms of palpitations, breathlessness and chest pain.

The association between HIV, cor pulmonale and pulmonary hypertension is well established. Common presentation of our patients with pulmonary hypertension was shortness of breath and in all cases it was attributed to lung disease.

These patients did not have any advanced immunosuppression, in other words there was no relation to the disease stage as reflected by CD4 count in these patients.

The majority of our patient's presentation was shortness of breath, which was actually out of proportion to the physical findings and the CD4 count was more than 250 cells.6,7 We found that there was no single predictor of pulmonary hypertension.

The echocardiographic picture was dilated right ventricle and dilated right atrium with prominent D-sign on the parasternal short-axis view. Main pulmonary artery was also dilated in most cases. The prognosis of these patients is usually poor. All the findings in our study in relation to cor pulmonale correlate well with previous research studies in this area.

\section{HIV and Myocarditis}

DCM is a documented cardiac abnormality in HIV patients. Patients with DCM had more advanced immunosuppression. In other words dilated cardiomyopathy in HIV was associated with advanced immunosuppression and lower CD4 cells. ${ }^{7}$

Myocarditis and direct HIV invasion of myocardial tissue are the most common causes of dilated cardiomyopathy in HIV patients.

\section{In our Study}

HIV patients with myocarditis presented with younger age group, lower systolic BP, lower diastolic BP, higher mean resting pulse rate, higher white blood cell, lower CD4 cell counts and symptoms of breathlessness and chest pain.

\section{All the Findings in our Study in Relation to Myocarditis}

Correlate well with previous research studies in this area, especially the low CD4 count, which is an excellent predictor of the presence of LV dysfunction. ART and proper nutrition has reduced the incidence of myocarditis. They improve survival and enhance quality of life.

\section{HIV and Pericardial Effusion}

In our study it was found that pericardial effusion was commonly seen in our HIV patients with a pattern ranging from asymptomatic effusions that are mild-to-severe pericardial effusion. Pericardial disease is the most common cardiovascular presentation of HIV infection and it was found to be independent of CD4 count and serum albumin levels. ${ }^{8} \mathrm{As}$ the incidence of HIV infection is on the rising trend, pericardial effusion and its sequential complications may become a major cardiac problem in future in HIV people.
Pericardiocentesis is not possible in most of these patients, because most of the detected effusions are small and even when indicated for the relief of tamponade, its diagnostic accuracy was found to be low.

HIV patients with pericardial effusion presented with younger age group, higher white blood cell, higher CD4 cell counts and symptoms of palpitations, breathlessness and chest pain.

All the findings in our study in relation to pericardial effusion correlate well with previous research studies in this area. HIV patients have an increased risk for pericardial effusions.

The development of pericardial effusion predicts a poor prognosis. This is because end stage HIV infection usually affects the pericardium through malignancies and infections.

\section{HIV and Systolic Dysfunction}

In HIV patients, studies show that systolic dysfunction is present in about one-third of the cases in echocardiographic studies. There has been a significant reduction in myocardial contractility.

As the disease become more and more severe, the myocardial dysfunction was found to be more.

The decrease in systolic function has been found to be the cause of increased mortality and morbidity in HIV patients and cardiac failure has been found to occur in about 5 percent of cases.

Hence, it is very important to screen for early diagnosis of systolic dysfunction to increase the life-span of the patients.

HIV patients with systolic dysfunction presented with lower systolic BP, higher haemoglobin level, higher white blood cell, lower serum creatinine, higher CD4 cell counts and symptoms of palpitations, breathlessness and chest pain. Usually, systolic dysfunction is associated with low CD4 count.

But in our study, it does not tally with previous research studies. All the findings in our study in relation to systolic dysfunction correlate well with previous research studies in this area.

\section{HIV and Diastolic Dysfunction}

The prevalence of diastolic dysfunction is found to be 30 percent in studies.

In HIV patients, the ventricles became more and more noncompliant and ventricular filling defects were noted in echocardiography signalling diastolic dysfunction. The dysfunction was found to be more severe in patients with advanced disease.

HIV patients with higher CD4 cell counts and symptoms of palpitations, breathlessness and chest pain. Diastolic dysfunction is also associated with low CD4 count. Again, here it does not tally.

Diastolic dysfunction may be the first indication of underlying cardiac disease in HIV. All the findings in our study in relation to diastolic dysfunction correlate well with previous research studies in this area.

Traditional risk factors also contribute to development of diastolic dysfunction. Asymptomatic diastolic dysfunction is common among HIV infected individuals. HIV infection and Zidovudine increase the risk of cardiac diastolic dysfunction. 8,9 
The symptoms of cardiac disease like of palpitations, breathlessness and chest pain were considerable in our study subjects.

They could be attributable to pulmonary disorders. Patients with HIV infection are known to develop multiple pulmonary opportunistic infections. ${ }^{10}$

All the patients with cardiac disease had anaemia. This may be due to advanced stage in HIV disease. Cardiac function will also be worsened by anaemia.

\section{CONCLUSIONS}

- $\quad 82 \%$ of the patients were males and $18 \%$ were females.

- Majority of the patients are in the age group 41-50 years.

- The male-female ratio is 4.5:1.

- $32 \%$ of the patients were confirmed with cardiac disease.

- $\quad 45.5 \%$ of the patients had CD4 count less than 200.

- $91 \%$ were on Anti-Retroviral Therapy.

- $8 \%$ of the males had the disease beyond 3 years.

- $53.5 \%$ of the patients were in the WHO HIV clinical stage 3.

- Most common echocardiographic diagnosis was myocarditis, pericardial effusion, systolic dysfunction and diastolic dysfunction, each at 7\% respectively.

- $\quad$ Smoking status correlated with HIV and coronary artery disease.

- $\quad$ Low CD4 count correlated with HIV and myocarditis.

\section{LIMITATIONS}

- Small sample size.

- Confounding factors like traditional risk factors of cardiac disease.

- Causal relationship cannot be established.

- Other predictors like viral load not studied.

\section{SUMMARY}

- Cardiac disorders in HIV infected individuals are common.

- Non-invasive investigations like echocardiography helps in early diagnosis of asymptomatic cardiac disease in HIV infected individuals.

- ART improves clinical outcomes in HIV infected individuals with cardiac disease.

\section{RECOMMENDATIONS}

- $\quad$ Large prospective studies are needed in order to confirm the observation in this study.
- Clinicians should be vigilant in addressing known risk factors for coronary disease in their patients with HIV infection and also should be aware of the various cardiovascular manifestations of HIV infection.

- CVD risk assessment and reduction measures should be implemented effectively, especially in HIV infected individuals.

- Lifestyle modification including smoking cessation, increased physical activity, weight reduction for those who are overweight or obese and education on healthy dietary practices should form part of activities of support groups tending to HIV infected individuals.

\section{REFERENCES}

1. Rerkpattanapipat P, Wongpraparut N, Jacobs LE, et al. Cardiac manifestations of acquired immune deficiency syndrome. Arch Intern Med 2000;160(5):602-8.

2. Prendergast BD. HIV and cardiovascular medicine. Heart 2003; 89:793-800.

3. Francis CK. Cardiac involvement in AIDS. Curr Probl Cardiol 1990;15(10):569-639.

4. Enger C, Graham N, Peng Y, et al. Survival from early, intermediate, and late stages of HIV infection. JAMA 1996;275(17):1329-34.

5. Monsuez JJ, Vittecoq D, Kinney EL. Increased survival of AIDS patients with heart disease within 10 years? Circulation 1996;94(9):2312-13.

6. d'Amati G, di Gioia CR, Gallo P. Pathological findings of HIVassociated cardiovascular disease. Ann N Y Acad Sci 2001;946:23-45.

7. Spira A, Marx PA, Patterson BK, et al. Cellular targets of infection and route of viral dissemination after an intravaginal inoculation of simian immune deficiency virus into rhesus macaques. J Exp Med 1996;183(1):215-25.

8. Dalgleish AG, Beverley PC, Clapham PR, et al. The CD4 (T4) antigen is an essential component of the receptor for the AIDS retrovirus. Nature 1984;312(5996):763-7.

9. Ariyoshi K, Harwood E, Chiengsong-Popov R, et al. Is clearance of HIV-1 viraemia at seroconversion mediated by neutralising antibodies? Lancet 1992;340(8830):1257-8.

10. Fisher SD, Lipshultz SE. Cardiovascular abnormalities in HIV-infected individuals. In: Braunwald E, eds. Heart disease: a text book of cardiovascular medicine. Philadelphia: WB Saunders 2001:2211-21. 